\title{
INFLUENCE OF CREATIVE PROBLEM SOLVING TO STUDY RESULT SOCIAL SCIENCES STUDY AS REVIEWED FROM THE MULTICULTURAL ATTITUDE OF STUDENTS CLASS V ELEMENTARY SOUTH KUTA
}

\author{
Andi Wapa ${ }^{1}$ \\ ${ }^{1}$ Universitas Bakti Indonesia \\ 1andiwapa933@yahoo.com
}

\begin{abstract}
This research aims to describe the effect of Creative Problem Solving learning implementation on social science learning results reviewed from multicultural attitudes. The research design uses Posttest only control group design. The primary school student research population is 401 students. The sample consisted of 120 students divided into two experiment classes and two control classes with random sampling group techniques. Data analysis is done with ANAVA. The results showed: a) the results of Social Science study between students who participated in Creative Problem Solving learning and students who participated in conventional learning with a score of $\left.F_{\text {cal }} 22,284>F_{\text {tab }}(3,93), b\right)$ influence between the application of creative problem solving learning and multicultural attitude to social science learning results with a score of $\mathrm{F}_{\mathrm{cal}} 66,428<\mathrm{F}_{\mathrm{tab}}(3.97)$, c) social science learning results between students who participate in creative problem solving and students who follow conventional learning, in students who have a high multicultural attitude with a score of $F_{\text {cal }} 31,396<$ $\left.F_{\text {tab }}(4,11), d\right)$ the results of social science studies between students who follow creative problem solving learning and students who follow conventional learning, students with a low multicultural attitude with a score of $\mathrm{F}_{\text {cal }} 9,928<\mathrm{F}_{\text {tab }}$ (4.11).
\end{abstract}

Keywords: creative problem solving, learning outcome of social science study, multicultural attitude.

\begin{abstract}
Abstrak
Penelitian ini bertujuan untuk mendeskripsikan pengaruh implementasi pembelajaran Creative Problem Solving terhadap hasil belajar Ilmu Pengetahuan Sosial ditinjau dari sikap multikultural. Rancangan penelitian menggunakan Posttest only control group design. Populasi penelitian siswa sekolah dasar sejumlah 401 siswa. Sampel terdiri dari 120 siswa yang dibagi menjadi dua kelas eksperimen dan dua kelas control dengan teknik group random sampling. Analisis data dilakukan dengan ANAVA. Hasil penelitian menunjukkan : a) hasil belajar Ilmu Pengetahuan Sosial antara siswa yang mengikuti pembelajaran Creative Problem Solving dan siswa yang mengikuti pembelajaran konvensional dengan nilai $\mathrm{F}_{\text {cal }} 22,284>\mathrm{F}_{\text {tab }}$ $(3,93)$, b) pengaruh antara penerapan pembelajaran creative problem solving dengan sikap multikultural terhadap hasil belajar Ilmu Pengetahuan Sosial dengan nilai $F_{\text {cal }} \quad 66,428<\mathrm{F}_{\text {tab }}$ $(3,97)$, c) hasil belajar Ilmu Pengetahuan Sosial antara siswa yang mengikuti pembelajaran creative problem solving dengan siswa yang mengikuti pembelajaran konvensional, pada siswa yang memiliki sikap multikultural tinggi dengan nilai $\mathrm{F}_{\text {cal }} 31,396<\mathrm{F}_{\text {tab }}(4,11)$, d) hasil belajar Ilmu Pengetahuan Sosial antara siswa yang mengikuti pembelajaran creative problem solving dengan siswa yang mengikuti pembelajaran konvensional, pada siswa yang memiliki sikap multikultural rendah dengan nilai $\mathrm{F}_{\text {cal }} 9,928<\mathrm{F}_{\text {tab }}(4,11)$.
\end{abstract}

Kata Kunci: hasil belajar ilmu pengetahuan sosial, creative problem solving, sikap multikultural.

\section{INTRODUCTION}

One of educational objectives in primary school in particular is to help students understand the problem that occur in the environment around the students or in daily life. In 
various education levels are taught certain subjects that can provide knowledge, so that can be used as reference in dealing with problems in everyday life. Social science is study of human behavior or human group meaning that a discipline that examines the behavior of human beings or human groups in society is categorizes social science. Sciense IPS is about social science that is directed to the occurrence of the students to themselves and the community environment (Lasmawan, n.d.)

The social science study in elementary school became indispensable to the development of the current era. In addition, it can give a better understanding of the character and attitude that students have in the future to live a pluralist life. The nation of Indonesia is a nation whose people are compounds or pluralists (Mahfud, 2016).

Recognizing the importance of the social science study, the Government has made many efforts to improve the quality of education, especially in the field of IPS education, including: (1) to make changes and improvements to the 1994 curriculum to 2004, then the Education Unit level Curriculum year 2006, and lately the government is implementing a curriculum 2013 in several schools, (2) increasing the education budget through the allocation of budget (20\%), (3) improving the competency of teachers through certification, and (4) procurement and improvement of school facilities and infrastructure through the School Operational Assistance Fund. At least with the changes made by the Government, can be a dynamic quality of education both in a wide and ecslative, so that education in the country is no longer harassed by other countries (Jamal Ma'ruf Asmani, 2014).

he quality of social sciences in Indonesia has not been said to be improved. This can be characterized by a number of conflicts that occur, which is not only happening in society but the student level also often do different students brawl of school. Because there is an immature attitude among students as the attitude of tolerance has become reduced. And they felt that the school that was occupied was more than the other school. Seeing from the incident was very clear that the education of IPS is closely related to the attitude in societal. So there needs to be an attitude of consciousness and mutual respect of the differences to avoid conflict that arise in society (Rufaida, 2017).

It is also supported by observations and interviews conducted in the V-class teacher at elementary school group II in South Kuta. Observation of observation during the learning process of IPS in class, obtained the following results. 1) Teaching teachers use the usual approach of teacher-centered approaches, without actively involving students, 2) students have not been able to determine the relation between social science study concept that one with the 
other social science study concept, 3) students can not explain back about the concept of learning materials that have been studied, 4) when the teacher gave a problem, students are still confused in finding the subject matter and what steps must be taken in finding answers to the question , 5) Students often ask to be led to solve a problem or do something and very rarely have students have their own initiative when they are about to study.

Moreover, based on the observation done in the South Kuta cluster II, the acquisition of data archive of the student exam semester results on the social science study, especially in class $\mathrm{V}$, the average value of the social science study of the students obtained only reached an average of 70 while the prescribed KKM is 75 . This indicates that the learning results of social science study can not be managed successfully.

The results of the observation are in line with the results of interviews. The interview was conducted with teachers of caregivers Study in social science study, presented with interviews, (1) teachers claimed to have difficulties in applying suitable models when conducting learning activities, (2) Often students can not find the aspect of the problem in the problem given by the teacher, teachers realize this because students are rarely trained on problem-based problems so that students feel confused when meeting such activities , (3) Students also have not been able to apply the concept of lessons with their lives, it is very apparent that lack of thought process ability can relate between real life and learning process, (4) in the learning process is also a teacher often use a direction learning process and does not relate real life to the learning process, so that the teacher is more dominant in the learning process than his.

Based on the problem found at elementary school cluster II in South Kuta, it needs improvement and renewal in the learning. This can be accomplished by applying learning that requires students to be directly involved in learning so that the learning outcomes in the IPS lessons are better. One of the alternatives in the improvement and renewal of the learning model that corresponds to the problem is to use the model Creative Problem Solving (CPS).

The concept of Creative Problem Solving (CPS) is not a new skill, but it does take into account the role of creativity in solving a problem. This is proven true as there is a link between human thinking and the context of life in which knowledge and skills in solving a problem can be developed and channelled through the application of daily life (Amran et al., 2019).

This Model allows the differences in learning results with the previous because students involve Lanngsung on the subject of (Malahayati, 2017). Students in the learning process can face the problem and make students grow in creativity. (Malahayati, 2017) stated, "CPS is a 
variation of the learning problem solving through systematic techniques in organizing creative ideas to Menyelessaikan a problem". With this model students will be involved directly and exist in solving the problems faced in real. This is in agreement with (Mudjiono, 2010) explaining about the matter in question being real or a suor which becomes a quaint question for the student.

These problems can train and experience the direct social activities are influential in the learning results of social science study in school. This is in line with the opinion of Pepkin (in Yanti, 2017) The CPS learning Model students are required to be able to find solutions that focuses on teaching and problem solving skills, followed by strengthening the creativity of the problem study Model solving very potential to train students creative thinking in the face of various problems, whether it is personal problems or group issues to be held on their own or together. The process should be made as interesting as it may depend on a teacher. Teachers play an important role in creating learning atmosphere that appeals to students (Mudjiono, 2010).

The CPS model has several characteristics that distinguish it from other models of learning. A prominent characteristic in this model is using problems as a source of learning and learning is conducted in a discussion group. (Kusuma, 2010) stated that broadly, CPS requires three processes of thought analysis, creative, and critical. The key is to adapt the three in the right order to resolve the problem.

Learning with a CPS model begins with several problems, then students choose what will be discussed in the learning activities so as to determine the subject matter. The problem that is used as a learning focus can be solved through group work so that it can provide diverse learning experiences to students such as cooperation and interaction in the group. Then students look for problems that have been provided so that they can determine the solution of a problem that has been determined. The situation shows that the CPS model in the learning demands readiness, both from the teacher and the student. Teachers act as facilitators and advisers, while students must be actively and independently involved in learning by optimizing their thinking skills. In other words, the use of CPS can improve student intelligence and can foster a bold attitude in presenting themselves to the learning of social science study.

Through CPS students are required to be skilled in choosing the problem, to be able to determine the solution in the learning activities, so that activities can affect the outcome of learning in the classroom. This is in line with the research conducted by (Widiani, 2016) and 
(Jauhar, 2017) which states, there are significant positive influences of CPS implementation towards students learning in addition (Eksan et al., 2015) in its research using CPS can increase the learning results reviewed from the student motivation. The same opinion conveyed by In his research to declare CPS more effective than conventional learning in mathematics lessons. Through this statement, students progress in thinking cratif in the study problem of social science study learning students. In addition Blank (Rufaida, 2017) says, the education value in the school has some positive elements. First, the field of value is so broad and so important that the school has a responsibility to engage in it. Secondly, there is a need in our community for more reflection on value, and the school can help its citizens to acquire the knowledge, skills and habits necessary to reflect it. This is in accordance with the lessons of IPS that are always related to the life of individuals or groups or people. In line with Supardan (Rufaida, 2017) stated the powerful social science study according to NCSS has characteristics such as, meaningful, integrity, value-based, challenging, and activating. So in the above opinion need a multicultural attitude in learning activities that can certainly influence the results of social science study.

\section{METHOD}

This research is a pseudo experimental research (quasi experiment), this research draft is an experimental study designed with $2 \times 2$ factorial design. In this study uses three variables consisting of one free variable, one bound variable and one moderator variable. The free variable in this study is the learning model of Creative Problem Solving (CPS) (A) as the variable of treatment, the bound variable is the outcome of learning $(\mathrm{Y})$ and the moderator variables in this study are the multicultural attitude (B).

Population is the totality of all possible values, whether calculating or measuring, quantitative or qualitative, than the specific characteristics of a complete and clear set of objects. The population in the study consisted of 401 students. Samples are determined by random sampling techniques. A research sample of 120 students was obtained by conducting equality tests in each class, one class as an experimental class, the other as a control class and an experimental Class.

The data collection method used is to provide multicultural attitude questionnaires before CPS learning treatments and conventional learning for research samples. Meanwhile, to get data on the learning outcomes of Social Science students obtained by providing questionnaire learning results after the enactment of CPS learning and conventional learning. 
The Data has been collected and analyzed using prerequisite tests and hypothesis tests using ANAVA AB. Thus, the data in this study is grouped into (1) The results of learning social science study of students who follow the CPS learning model, (2) The results of social science study learning that follow conventional learning, (3) The results of learning social science study students who follow a CPS learning model that has a high multicultural attitude, (4) The results of learning social science study students who follow the model of , (5) The results of learning social science study students who follow conventional learning that has a high multicultural attitude, (6) The results of learning social science study students who follow conventional learning that has a low multicultural attitude. The entire analysis process is assisted by the SPSS 16.00 for Windows application.

\section{RESULTS AND DISCUSSION}

\section{Results}

The object in this study is the difference in learning results of social science students as a result of the treatment between the implementation of Creative Problem Solving model and conventional learning by considering students ' multicultural attitudes. Calculation of the central size (mean), data spread size (standard deviation),

Table 1. Calculation of the results and social science study learning score statistic

\begin{tabular}{ccccccc}
\hline Statistik & A1 & A2 & A1B1 & A2B1 & A1B2 & A2B2 \\
\hline Mean & 83,97 & 77,69 & 91,55 & 80,05 & 77,50 & 71,79 \\
Standar Deviasi & 7,86 & 6,60 & 5,74 & 7,04 & 6,74 & 4,22 \\
Varians & 61,84 & 43,55 & 32,89 & 49,61 & 45,42 & 17,84 \\
Maximum score & 100,00 & 89,00 & 100,00 & 89,00 & 89,00 & 79,00 \\
Minimum score & 68,00 & 65,00 & 83,00 & 69,00 & 68,00 & 65,00 \\
Range & 32,00 & 24,00 & 17,00 & 20,00 & 21,00 & 14,00 \\
\hline
\end{tabular}

Description :

$\mathrm{A}_{1} \quad$ : Learning results of social science study Students who follow CPS learning.

$\mathrm{A}_{2} \quad$ : Learning results students who follow Conventional learning.

$\mathrm{A}_{1} \mathrm{~B}_{1}$ : Learning results of social science study students who follow the CPS learning wich has a high multidiciplinary attitude.

$\mathrm{A}_{1} \mathrm{~B}_{2}$ : Learning results students who follow the CPS learning that has a low multicultural attitud.

$\mathrm{A}_{2} \mathrm{~B}_{1}$ : Results of learning social science study student who follow conventional learning that has a high multicultural attitud.

$\mathrm{A}_{2} \mathrm{~B}_{2}$ : Results of learning social science study student who follow conventional learning that has a high multicultural attitud 
The average learning outcomes score for students following CPS (A1) is 83.96 categorized as very high. The average learning outcome that follows conventional learning (A2) is 77.68 including high catagories. On average, the results of IPS learning that follows CPS learning that has a high multicultural attitude (A1B1) is 91.55, including very high category. The average learning score of IPS that follows CPS learning that has a low multicultural attitude (A1B2) is 77.50 including high category. The average learning results score that follows conventional learning that has a high multicultural attitude (A2B1) is 80.05 in very high category. The average learning results score that follows conventional learning that has a low multicultural attitude (A2B2) is 71.78 included in the high category.

The test results of the normality of data spread tested by the technique KolmogorovSmirnov help SPSS 16.00 for Windows has significance numbers greater than 0.05 . Thus, all data spreads according to the normal distribution learning model. Test the homogeneity of the learning results resulted in a significance value of 0.403 , a study result with a high multicultural attitude resulted in significance numbers of 0.235 . and results Belajara learn that has a low multicultural attitude to finish the significance number of 0.063 . Based on the results the analysis appears that the resulting significance number is greater than 0.05 . Thus it can be concluded that the learning variables of social science study, learning outcomes that have a high multicultural attitude, and the resultant learning that has a low multicultural attitude is homogeneous.

The hypothesis test in this study was conducted through statistical methods using ANAVA AB formula. Furthermore, if there is a interaction between the multicultural attitude of the students to the learning results of social science study, it is represented by the Tukey test to determine the effect of the interaction which is better. ANAVA AB calculation result is done using SPSS 16.00 program.

\section{Discussion}

The results of ANAVA AB's analysis with assisted SPSS 16.00 for Windows shows first hypothesis testing, rejected nul hypotheses and alternative hypotheses received (analysis results: The significance value of "model" $(\mathrm{A})=39.508)(\mathrm{Sig} .<0.050))$. This means there is a significant difference in the results of the IPS learning between students who follow CPS learning higher than those who follow conventional learning in IPS learning. Second hypothesis testing, nul hypothesis rejected and alternative hypotheses received (Results of analysis: The significance value "model * multicultural Attitude" $(\mathrm{A} * \mathrm{~B})=4.468$ (Sig. $<$ 
0.050)). This means there is a significant influence of interaction between learning models in IPS learning and the multicultural attitude of students to the learning outcomes of IPS students. The third hypothesis test, the nul hypothesis was rejected and the alterlnative hypothesis was received $($ Qtabel $(0.050)=4.11$, Qcount $=8.518$, Qcount $>$ qtable $)$. This means there is a significant difference between the learning outcomes of IPS students who have a high multicultural attitude when they are given treatment using CPS learning and conventional learning. Fourth hypothesis testing, the $\mathrm{Nu}$ hypothesis was rejected and alternative hypothesis was received $($ Qtabel $(0.050)=4.11$, Qcount $=4.237$, Qcount $>$ qtable $)$. This means there is a significant difference between the learning outcomes of IPS students who have low multicultural attitudes when they are given treatment using CPS learning and conventional learning.

Based on the results of the analysis, it is theoretically said that the CPS model is a learning that is used to stimulate students ' thinking in situations that are oriented towards realworld problems, because the first thing that is done in dealing with the problem is to deal with it in order to define it and gather data related to the problem (Kusuma, 2010). This learning provides a meaningful experience such as solving problems by giving students the freedom to choose actions and analyse actions through discussions so as to build knowledge in themselves, understand each other's disagreements, decide the best decision and can influence the results of the social science study learning.

The CPS learning Model is: a). Give learners the opportunity to understand concepts by resolving a problem, B). Making learners active in learning, c). Develop learners ' thinking skills because they are presented with problems at the beginning of learning and give students more flexibility to find their own completion directions, D). Develop learners ' ability to solve problems, collect data, analyze data, build hypotheses, and experiment to solve a problem, E). Making learners can apply the knowledge they already have into new situations.

The findings in this study are in line with the results of the research conducted by (Widiani, 2016) on the learning model of Creative Problem Solving to improve activity in citizenship education class IV courses of orange juice. It was concluded that the percentage of the number of students who successfully reached the research success indicator experienced an increase from the pre action of $0 \%$ of students, $\mathrm{I} / 1$ cycle was only $7.14 \%$ students, cycle $\mathrm{I} / 2$ to $28.57 \%$ students. On cycle II/1 as much as $64.29 \%$ students then cycle II/2 to $100 \%$ students. The (Jauhar, 2017) In his research shows, the learning of IPS by using the Problem Solving 
model is better in improving student learning outcomes compared to conventional learning. Referring to the findings and results of relevant research, it is evident that CPS is more effective than conventional learning towards IPS learning outcomes in elementary schools.

Learning with a CPS model will enable students to engage in a variety of learning resources in the form of courage, confidence, and multicultural attitudes and learning freedom to achieve optimal learning outcomes. The results showed that the average student learning value that used a CPS learning model of 83.97 was higher than the value of student learning that used a conventional model of 77.69. ANAVA test results show that the value of F count is $22.284>\mathrm{F}$ table of 3.93 which indicates that there is a significant difference in the results of the IPS learning between the groups that follow the Creative Problem Solving learning model with groups of students who follow conventional learning models.

Looking at the results of the research, theoretically, the multicultural attitude of the pin is very influential in the learning outcomes of IPS students, both in the CPS learning and on conventional learning. Because the lack of multicultural attitudes that are owned by the students will also affect the learning outcomes.

Learning with a CPS model in the social science study subject is much longer remembered and understood because students of the problems used are contextual and in solving students ' problems independently can solve it by thinking logically based on existing learning resources. The learning process will be more meaningful when the student is in control of his or her own knowledge and experience directly from what he learns. CPS learning in the process, students can select several subject matter then students collectively group discussions to determine the problem and look for solutions. A student-centered learning system will be more experienced and feel more direct learning so that students can build their own knowledge. The findings in this study are in line with the results of research conducted by (Rufaida, 2017) which indicates that there is a influence of multiticulural attitudes of students on the learning results of IPS.

Differences in the results of social science study between students who follow Creative Problem Solving Model with students who follow conventional learning Model in students who have high multicultural attitude this is evidenced by the value F count of $31.396>4.11$ and the average value also shows that the value of student learning that uses Creative Problem Solving learning model is higher than 91.55 of the control class which uses conventional learning model with average of 80.05 . 
Multicultural attitude is a development process that does not recognize the partition in human interaction. As a potential development attraction, multicultural attitude is an attitude that appreciates heterogeneity and plurality, education that upholds the value of culture, ethnicity, ethnicity, and religion. Multicultural attitude is one of the important components in the learning process, especially in the content of social science study. By having a multicultural attitude students will grow several dimensions namely: (1) Dimension of content integration/material (content Integration), (2) Knowledge construction dimension, (3) Prejudice reduction Dimension, (4) Equal/fair education dimension (Equitable Pedagogy), (5) Dimension of school culture empowerment and social structure (empowering school culture and social structure) (Mahfud, 2016).

Differences in the results of social science study learning between students who follow Creative Problem Solving Model with students who follow conventional learning Model in students with low multicultural attitude this is evidenced by the value $\mathrm{F}$ count of $9.928>4.11$ and the average value also shows that the student learning value using the Creative Problem Solving learning model is higher than 77.50 of the control class that uses conventional learning model with an average of 71.79 .

Conventional learning models emphasize the teacher's role as an informed teacher centered. In the process of learning the teacher does not act as a facilitator and mediator but as a holder of authority in learning, so the learning process on conventional learning models takes place under the control of teachers so that students are passive and inactive in learning activities. Students only act as recipients of knowledge informed by the teacher and then memorize it. The learning process tends to take One direction, which is from teacher to student. For students with low multicultural attitudes able to absorb and receive learning with this conventional model.

Learning with the creative problem model solving requires students to be active in the learning process. Students are given the opportunity to assimilate information by exploring a draft investigate concept then accommodating the information obtained with the introduction of the concept. Students with a low multicultural attitude are difficult to absorb learning by using this learning model. Because students who have low multicultural attitudes in general are passive, less curious, less critical, not diligent, easily bored and unmotivated in the learning process.

The results showed students ' learning outcomes with a creative problem solving model that had a low multicultural attitude had a higher average value compared to the value of student 
learning outcomes with conventional models. This is because the model of creative problem solving able to encourage students with a low multicultural attitude to contribute to improve the learning outcomes because they want to not want students to follow the learning process. So that the average value of students with a creative problem solving model is higher than the average value of students with conventional models.

\section{CONCLUSION}

This research is a pseudo experiment research (QUASAI experiment) with draft research Posttest only control group design population in this research is a student of class V in South Kuta group II consisting of 6 classes with a total of 401 people. Through the group random sampling technique, selected VA class SD No. 6 Benoa and Class V SD No. 2 Tanjung Benoa as experimental class (with Creative Problem Solving) class VB SD No. 6 Benoa and VC class SD No. 2 Tanjung Benoa as the control class (with conventional learning).

The Data collected in this research is the result of learning social science study and multicultural attitudes of students. In this study, the learning results of social science study are defined as skills in the social science study field in the students ' own affective area after receiving the social science study learning experience based on the prescribed learning objectives. The results of the IPS study were measured using the social science study learning questionnaire compiled based on freedom of independence and maintaining independence. The questionnaire developed in this study was a questionnaire that numbered 20 items. Multicultural attitudes instruments consist of 30 positive statements. This instrument uses a Likert scale consisting of five response options. The design of the data analysis used is the descriptive analysis and analysis of ANAVA AB. Prior to the hypothesized test, a prerequisite analysis test was conducted, namely the normality test and homogeneity test. Based on the results of the research and the discussion that has been outlined in this thesis is there are several conclusions obtained. The following conclusions are obtained from the research results:

There are differences in the results of the social science study learning between groups of students who follow CPS learning with groups of students who follow conventional learning.

There is a influence on the interaction of CPS learning model with conventional learning is reviewed from the student's multicultural attitude towards the learning outcomes of social science study. 
There are differences in the results of the social science study learning, among groups of students who follow the CPS learning with groups of students who follow conventional models in students who have high multicultural attitudes.

There are differences in the results of the social science study learning, among groups of students who follow the CPS learning with groups of students who follow conventional models in students who have high multicultural.

\section{ACKNOWLEDGMENTS}

This research is conducted at a self-cost, without the use of any party sponsor.

\section{REFERENCES}

Amran, M. S., Kutty, F. M., \& Surat, S. (2019). Creative Problem-Solving (CPS) Skills among University Students. Creative Education, 10(12), 3049-3058.

Eksan, M. B. S., Wiguna, F. A., \& Wahyu, N. (2015). Penerapan Creative Problem Solving (Cps) Dan Ideal Problem Solving Berbasis Pengalaman Nyata (Experiencing) Ditinjau Dari Motivasi Belajar Mahasiswa. Jurnal Kependidikan, 3(1), 58-67.

Jamal Ma’ruf Asmani. (2014). 7 Tips Aplikasi Pakem. Dive Pres.

Jauhar, S. (2017). Penerapan Model Pembelajaran Problem Solving Dalam Meningkatkan Hasil Belajar IPS Siswa SD. JIKAP PGSD: Jurnal Ilmiah Ilmu Kependidikan, 2(1), 141.

Kusuma, Y. (2010). Creative problem solving. Tanggerang Selatan. Jelaja Nusa.

Lasmawan, W. (n.d.). Pembelajaran Ilmu Pengetahuan Sosial Dengan Model. Singaraja. Undiksha.

Mahfud, C. (2016). Pendidikan Multikultural. Yogyakarta. Pusaka Belajar.

Malahayati, E. N. (2017). Pengaruh Lembar Kerja Siswa (LKS) Berbasis Creative Problem Solving (CPS) Pada Materi Keanekaragaman Hayati Untuk Meningkatkan Berpikir Kritis dan Hasil Belajar Siswa Kelas X SMAN 4 Blitar. Konstruktivisme, 9(2), 147-158.

Mudjiono, D. (2010). Belajar Dan Pembelajaran. Jakarta. Renika Cipta.

Rufaida, H. (2017). Menumbuhkan Sikap Multikultural Melalui Internalisasi Nilai-. SOSIO DIDAKTIKA: Social Science Education Journal, 4(1), 14-24.

Widiani, N. (2016). Penerapan Model Pembelajaran Creative Problem Solving Untuk Meningkatkan Keaktifan Siswa Dalam Pembelajaran PKn. Jurnal Pendidikan Guru Sekolah Dasar Edisi 11, 11(5), 62-73. 